\title{
MASTER
}

\section{Review of Zirconium-Zircaloy Pyrophoricity}

Date Published: November 1984

\author{
Thurman D. Cooper \\ Research and Engineering \\ Prepared for the U.S. Department of Energy \\ under Contract DE-AC06-77RL01030
}

RHO-RE-ST- $-31 P$

DE85 011169

\section{DISCLAIMER}

This report was prepared as an account of work sponsored by an agency of the United States Government. Neither the United States Government nor any agency thereof, nor any of their employees, makes any warranty, express or implied, or assumes any legal liability or responsibility for the accuracy, completeness, or usefulness of any information, apparatus, product, or process disclosed, or represents that its use would not infringe privately owned rights. Reference herein to any specific commercial product, process, or service by trade name, trademark, manufacturer, or otherwise does not necessarily constitute or imply its endorsement, recommendation, or favoring by the United States Government or any agency thereof. The views and opinions of authors expressed herein do not necessarily state or reflect those of the United States Government or any agency thereof.

\section{Rockwell International \\ Rockwell Hanford Operations}

PO Box 800

Richland, Washington 99352 


\section{DISCLAIMER}

This report was prepared as an account of work sponsored by an agency of the United States Government. Neither the United States Government nor any agency Thereof, nor any of their employees, makes any warranty, express or implied, or assumes any legal liability or responsibility for the accuracy, completeness, or usefulness of any information, apparatus, product, or process disclosed, or represents that its use would not infringe privately owned rights. Reference herein to any specific commercial product, process, or service by trade name, trademark, manufacturer, or otherwise does not necessarily constitute or imply its endorsement, recommendation, or favoring by the United States Government or any agency thereof. The views and opinions of authors expressed herein do not necessarily state or reflect those of the United States Government or any agency thereof. 


\section{DISCLAIMER}

Portions of this document may be illegible in electronic image products. Images are produced from the best available original document. 
.

• 


\section{DISTRIBUTION}

This report has been distributed according to the categories "Materials," UC-25, and "Health and Safety," UC-41, as given in the Standard Distribution for Unclassified Scientific and Technical Reports, TIC-4500. 
. 


\section{ACKNOWLEDGMENTS}

The author extends his thanks and appreciation to the authors of the referenced documents for the extensive body of pertinent literature they provided, and to Dr. V. F. Baston, consultant to GPO Nuclear, and

Dr. J. R. Jewett, Mr. J. O. Henrie, and Mr. T. A. Lane, Rockwe 11 Hanford Operations, for their many helpful suggestions in the preparation and editing of this document. 
. 
RHO-RE-ST-31 P

CONTENTS

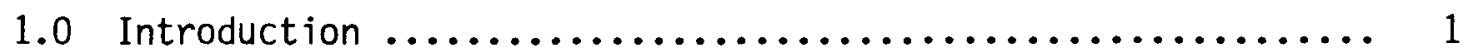

2.0 Zircaloy Metal Characterization ................... 1

3.0 Zirconium Ignition Characteristics $\ldots \ldots \ldots \ldots \ldots \ldots \ldots \ldots \ldots$

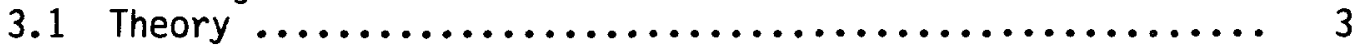

3.2 Zirconium Powders ........................... 4

3.3 Zirconium Turnings, Shavings, and Coarse Powders ...... 11

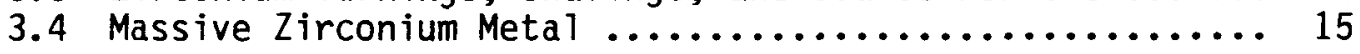

4.0 Industrial Zirconium Incidents $\ldots \ldots \ldots \ldots \ldots \ldots \ldots \ldots \ldots$

5.0 Recommendations for Handling, Shipping, and Storage ....... 18

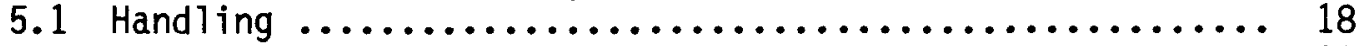

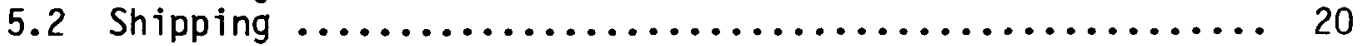

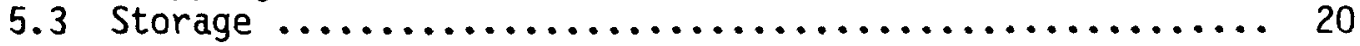

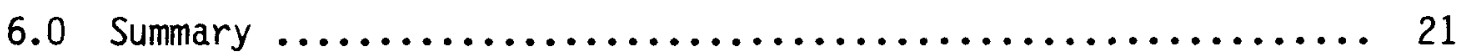

7.0 References $\ldots \ldots \ldots \ldots \ldots \ldots \ldots \ldots \ldots \ldots \ldots \ldots \ldots \ldots \ldots \ldots \ldots \ldots$

FIGURES:

1. Ignition Temperature of Zirconium Metal as a Function

of Surface Area per Gram ..................... 7

2a. Relationship of Critical Mass to Particle Size for

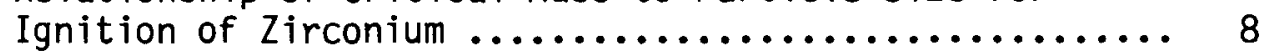

2b. Relationship of Critical Mass to Temperature for

Various Particle Sizes of Zirconium ............... 9

3. Ignition Temperature of Zirconium as a Function of Specific Area .............................. 10

4. Minimum Electrical Energy to Ignite Dust Clouds of Titanium ................................. 12

5. Limiting 0xygen Content in Air-Inert Gas Mixtures for Preventing Ignition of Dust Clouds by Electric Spark ... 13

TABLES:

1. Chemical Composition of Zircaloy Alloys ............ 2

2. Core Design Parameters for 1,000 MW Light-Water

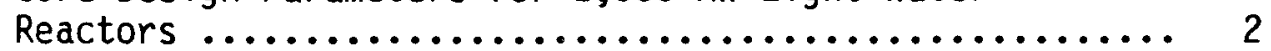

3. Zirconium Powder Ignition Characteristics ........... 5

4. Physical Relationships in Assessing the Safety

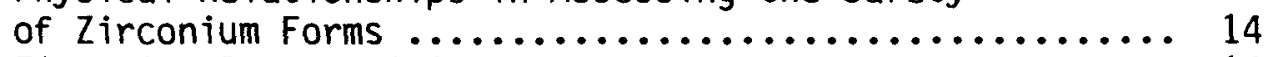

5. Zirconium Pyrophoricity Hazards .................... 14

6. Ignition Tests Performed on Zircaloy Tubing Sections ... 16 


\subsection{INTRODUCTION}

Zirconium metal is used to encapsulate reactor fuel because of its low neutron-capture cross section and other desirable properties.

Zirconium tubing or sheets greater than $0.3 \mathrm{~mm}$ thick and individual particles greater than $3 \mathrm{~mm}$ in the smallest dimension are considered safe from flammability or pyrophoricity hazards. Most of the zirconium used within industry meets this definition and is quite safe to handle.

Finely divided zirconium can be flammable or pyrophoric under certain conditions. Fortunately, specific handling and storage practices have evolved that permit finely divided powder to be handled and stored safely. Such powder is usually wetted with 25 percent or more water by weight. Alternatively, pyrophoric powder can be stored under an inert gas cover in special situations where water is not desirable.

Zirconium is not unique in exhibiting pyrophoricity. The difference between zirconium and other combustible materials such as iron, uranium, copper, flour, sawdust, coal, magnesium, or oily rags is one of degree only. With the exception of the noble metals, all of the common metals oxidize in air. Under the proper conditions, they may burn or self-ignite; for example, iron, copper, and nickel (0.01-0.03 $\mu \mathrm{m}$ in particle size), tungsten $(1 \mu \mathrm{m})$, and zirconium and sodium $(10 \mu \mathrm{m})$ will all spontaneously ignite in air on disturbance or light impact.

In the following sections of this literature review (References 1 through 28), the ignition characteristics of various zirconium particles and metallic shapes, as well as techniques for safely handling and storing zirconium, are discussed.

\subsection{ZIRCALOY METAL CHARACTERIZATION}

Zircaloy is a name given to a group of zirconium metal alloys. Zircaloy-2 is an alloy used to clad most Boiling Water Reactor (BWR) fuels and Zircaloy-4 clads most Pressurized Water Reactor (PWR) fuels. The chemical composition of both these alloys is given in Table 1 . Zircaloy is typically 98 percent or more zirconium, which leads one to suspect its pyrophoricity would be similar to pure zirconium metal. In fact, laboratory experiments have confirmed this similarity. (Reference 2)

The principal Zircaloy source in the reactor core is the fuel pin cladding. Table 2 (from Reference 2) contains data pertaining to the dimensions of the fuel pin cladding and the total amount of Zircaloy in a typical 1,000 MW Light-Water Reactor (LWR). 
TABLE 1. Chemical Composition of Zircaloy Alloys.

\begin{tabular}{l|l|c}
\hline \multirow{2}{*}{ Element } & \multicolumn{2}{|c}{ Concentration, wt\% } \\
\cline { 2 - 3 } & Zircaloy-2* & Zircaloy-4 \\
\hline Tin & $1.20-1.70$ & 1.60 \\
Iron & $0.07-0.20$ & 0.225 \\
Chromium & $0.05-0.15$ & -- \\
Nicke1 & $0.03-0.08$ & -- \\
Zirconium & Balance & Balance \\
\hline
\end{tabular}

*ASTM.

TABLE 2. Core Design Parameters for 1,000 MW Light-Water Reactors.

\begin{tabular}{l|c|c}
\hline \multicolumn{1}{c|}{ Parameter } & BWR & PWR \\
\hline Core fuel loading, MTU & 139.34 & 86.286 \\
Fuel, pins/core & 35,280 & 39,372 \\
Cladding tube length, cm & 406.4 & 380.2 \\
Cladding outside diameter, cm & 1.43 & 1.09 \\
Cladding inside diameter, cm & 1.27 & 0.962 \\
Cladding thickness, cm & 0.0813 & 0.0617 \\
Cladding material & $\mathrm{Zr}-2$ & $\mathrm{Zr}-4$ \\
Cladding density, g/cm 3 & 6.55 & 6.6 \\
End cap diameter, cm & 1.43 & 1.09 \\
End cap length, cm & 1.75 & 1.75 \\
Total zirconium mass, kg/core & $3.32 \times 10^{4}$ & $2.12 \times 10^{4}$ \\
\hline
\end{tabular}


From Table 2, the fuel pins are observed to be approximately $4 \mathrm{~m}$ long by approximately $1 \mathrm{~cm}$ in diameter and the cladding is approximately $0.6 \mathrm{~mm}$ thick. Zirconium cladding is therefore massive in size (as defined in

Section 3) and is not considered a flammability hazard. Any mechanical or chemical process that reduces the cladding to turnings, chips, granules, or powders can, however, generate a pyrophoricity or flammability hazard.

\subsection{ZIRCONIUM IGNITION CHARACTERISTICS}

\subsection{THEORY}

A mathematical description of the parameters affecting zirconium equilibrium temperatures was presented by DeHollanderer (Reference 1)*. He derives the following equation by assuming an equilibrium between the heat produced by surface oxidation and the heat lost to the environment:

$$
T_{1}=\frac{E}{9.14 \log \frac{\left(3 Q A^{\frac{1}{2}} \mathrm{rm}\right)}{\left(J \mathrm{dpt} t^{\frac{1}{2}}(\Delta t)\right.}}
$$

where

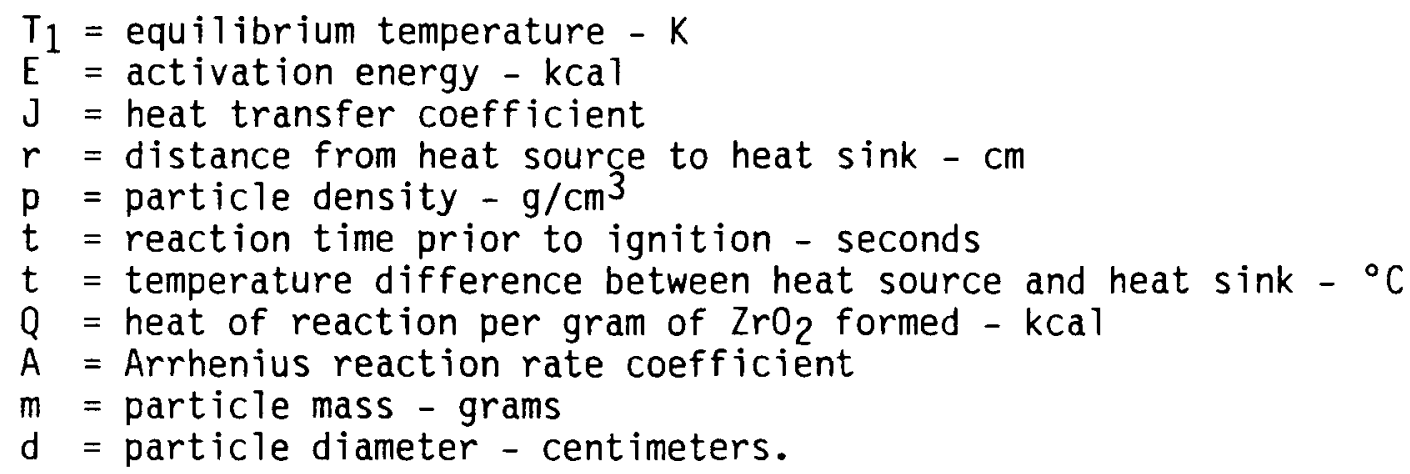

If the sample comes to equilibrium before it reaches the ignition temperature, no ignition results; however, if ignition is achieved, the ignition temperature could not be higher than this value.

\footnotetext{
«Dehollanderer's equation is derived with sample mass as a variable. Anderson and Belz (Reference 27) perform a similar derivation that ignores the sample mass. They further relate $T_{1}$ to the cube root of that mass for maximum heat source to heat sink distance $(r)$.
} 
From this equation the following inferences may be made.

- The greater the distance, $r$, that heat must travel to be lost from the sample, the lower the apparent equilibrium temperature.

- The greater the mass of sample, the lower the temperature; i.e., the more powder, the lower the temperature.

- The smaller the diameter of each particle in the sample, the lower the equilibrium temperature.

- The less reaction time it takes to ignite the sample, the lower the equilibrium temperature.

- If, at any given ambient temperature $T_{1}$, a small sample does not ignite in a short time, it probably won't ignite; conversely, a very large pile of powder may ignite at a low temperature after a very long time.

- The greater the activation energy for the oxidizing reaction, the higher the equilibrium temperature.

- The greater the heat produced per gram of oxide formed, the lower the equilibrium temperature.

- The denser the sample, the higher the equilibrium temperature.

- The better insulated the sample, the lower the equilibrium temperature.

\subsection{ZIRCONIUM POWDERS}

The following observations for zirconium powder ignition characteristics are drawn from Table 3. Zirconium dust clouds, with particle diameters less than $45 \mu \mathrm{m}$, burst into flames when the powder is puffed into room temperature air. The ignition temperature in atmospheres of carbon dioxide and/or nitrogen will be a function of particle size and will be different from the temperatures experienced in oxygen atmospheres. Ignition of a11 zirconium particles smaller than $44 \mu \mathrm{m}$ was observed at $550^{\circ} \mathrm{C}$ in carbon dioxide and $520^{\circ} \mathrm{C}$ in nitrogen. (Reference 29)

Inert material, such as sand, may be mixed with pyrophoric powders to damp the explosions. Ninety percent or more inert material was required to damp the explosions of dust clouds of samples 10, 11, and 12 .

Dust clouds may also be ignited by electrical sparks $(0.25 \mathrm{msec})$ containing as little as $5 \mathrm{~mJ}$ of energy. The human body is capable of storing $10 \mathrm{~mJ}$ of energy that may discharge to ignite some of these clouds. 
TABLE 3. Zirconium Powder Ignition Characteristics.

\begin{tabular}{|c|c|c|c|c|c|c|c|c|c|c|c|c|c|c|}
\hline \multirow{3}{*}{$\begin{array}{l}\text { Samip le } \\
\text { number }\end{array}$} & \multirow{3}{*}{$\begin{array}{l}\text { Sample } \\
\text { type }\end{array}$} & \multirow{3}{*}{$\begin{array}{c}\text { Average } \\
\text { particle } \\
\text { diameter } \\
\mu \mathrm{m}\end{array}$} & \multicolumn{6}{|c|}{ Furnace ignition temperature ${ }^{\circ} \mathrm{C}$} & \multirow{2}{*}{\multicolumn{2}{|c|}{$\begin{array}{c}\text { Relative } \\
\text { flammability }\end{array}$}} & \multirow{2}{*}{\multicolumn{2}{|c|}{$\begin{array}{l}\text { Spark energy } \\
\text { ignition }\end{array}$}} & \multirow{3}{*}{$\begin{array}{c}\begin{array}{c}\text { Lower } \\
\text { explosive } \\
\text { limit }\end{array} \\
\text { g/L }\end{array}$} & \multirow{3}{*}{ Reference } \\
\hline & & & \multicolumn{3}{|c|}{ Dust clouds } & \multicolumn{3}{|c|}{ Dust layers } & & & & & & \\
\hline & & & Air & $\mathrm{CO}_{2}$ & $\mathrm{~N}_{2}$ & Air & $\mathrm{CO}_{2}$ & $\mathrm{~N}_{2}$ & $\begin{array}{l}700^{\circ} \mathrm{C} \\
\text { furnace }\end{array}$ & $\begin{array}{l}\text { Spark } \\
\text { appartus }\end{array}$ & $\begin{array}{l}\text { Dust } \\
\text { cloud } \\
\mathrm{mJ}\end{array}$ & $\begin{array}{l}\text { Dust } \\
\text { layer } \\
\mu \mathrm{J}\end{array}$ & & \\
\hline 1 & $2 r$ & 208 & & & & 378 & & & & & & & & 1 \\
\hline 2 & $2 r$ & 5.0 & & & & 312 & & & & & & & & 1 \\
\hline 3 & $2 r$ & 15.4 & & & & 181 & & & & & & & & 1 \\
\hline 4 & $2 r$ & 28.2 & & & & 200 & & & & & & & & 1 \\
\hline 5 & $2 r$ & 36.4 & & & & 187 & & & & & & & & 1 \\
\hline 6 & $2 r$ & 106 & & & & 222 & & & & & & & & 1 \\
\hline 7 & $\mathrm{Zr}$ & 284 & & & & 171 & & & & & & & & 1 \\
\hline 8 & $2 r$ & & 20 & & & & & & & & 15 & & & 1 \\
\hline 9 & $2 r$ & & 20 & 650 & $N i \star$ & 190 & 650 & 790 & & & & & & 2 \\
\hline 10 & $2 r$ & $<45$ & 20 & & & 210 & 560 & 530 & $90+$ & $90+$ & 40 & & 0.19 & 3 \\
\hline 11 & $\mathrm{Zr}$ & $<45$ & 20 & & & 260 & & & $90+$ & $90+$ & 15 & 0.4 & 0.04 & 3 \\
\hline 12 & $Z r$ & 3.0 & 20 & & & 220 & & & $90+$ & $90+$ & 5 & 1.0 & 0.04 & 3 \\
\hline 13 & $\mathrm{Zr}$ & 3.3 & 20 & 650 & $\mathrm{Ni}$ & 190 & 620 & 790 & & & 15 & 6.4 & 0.04 & 3 \\
\hline 14 & $\mathrm{ZrH}_{2}$ & 15 & 350 & & & 270 & & & 85 & 80 & 60 & 320 & 0.08 & 3 \\
\hline 15 & $\mathrm{ZrH}_{2}$ & 4.7 & 430 & $\mathrm{Ni} \star$ & $\mathrm{Ni} *$ & 340 & 650 & $\mathrm{Ni}^{\star}$ & & & 100 & 64 & 0.12 & 3 \\
\hline
\end{tabular}

$\star N i$ - Nonignitable at maximum furnace temperature $\left(850^{\circ} \mathrm{C}\right)$ 
The lower explosive concentration limit for zirconium dust clouds ranges from 0.04 to $0.19 \mathrm{~g} / \mathrm{L}$ of air for the samples tested. This concentration range approaches the concentrations typically treated with cyclones $(0.23 \mathrm{~g} / \mathrm{L})$, and is much higher than the occupational employee exposure limit of 1.5 by $10^{-5} \mathrm{~g} / \mathrm{L}$.

Dust layers required much higher ignition temperatures (171 to $378^{\circ} \mathrm{C}$ ) than dust clouds. Dehollanderer (Reference 1) supposedly found an inverse relation between the ignition temperature of dust layers and the log of the specific surface area (Fig. 1). His data points are quite scattered and his correlation may require additional proof.

Both dust clouds and dust layers ignited in a carbon dioxide atmosphere. Dust layers also ignited in nitrogen at 530 to $790^{\circ} \mathrm{C}$, contrary to the behavior of dust clouds. This behavior is quite puzzling and additional work on this strange dichotomy might prove useful.

In summary, one may conclude that finely divided zirconium powder is pyrophoric and that high dust loadings may ignite at room temperature when dry and disturbed or puffed into the air. Dust layers are much more difficult to ignite thermally. Conversely, dust layers are more susceptible to spark initiated ignition than dust clouds.

Figures $2 a$ and $2 b$ (from Reference 2) display the relationship between critical mass and particle diameter, and ignition temperature. Figure $2 a$ plots the $\log$ of the critical mass as a function of the particle diameter for 60,80 , and $100^{\circ} \mathrm{C}$. According to this figure, $7-\mu \mathrm{m}$ powder requires $230 \mathrm{~kg}$ of zirconium to reach a critical mass leading to pyrophoricity at $60^{\circ} \mathrm{C}$. Approximately $8 \mathrm{~kg}$ are required at $100^{\circ} \mathrm{C}$. This illustrates the large effect temperature has upon promoting pyrophoricity. To create a critical mass at $100^{\circ} \mathrm{C}, 230 \mathrm{~kg}$ of $25-\mu \mathrm{m}$ powder are required; however, only

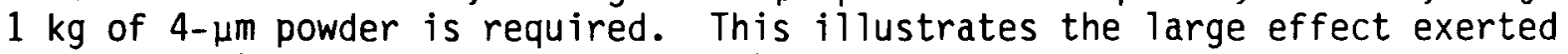
by the particle diameter on pyrophoricity.

One concludes that very small diameter particles are extremely pyrophoric and must be handled in very small amounts or underwater to avoid pyrophoricity.

Figure $2 b$ plots the log of the critical mass against the inverse of the temperature and obtains a linear correlation for particles of uniform size. Again the smallest particles are seen to be extremely pyrophoric. A close examination of this graph shows the 1-um powder has a smaller slope and is less temperature dependent than the larger diameter powders.

Figure 3 (from Reference 2) plots the ignition temperature of zirconium powder as a function of the log of the specific area. A linear correlation with negative slope is convincingly demonstrated, and one may conclude that the larger the specific surface area, the lower the ignition temperature.

The minimum electrical energy required to ignite pyrophoric dust clouds, as a function of dust concentration, is of interest. This is difficult to measure for zirconium since micrometer-sized dry zirconium dust clouds 


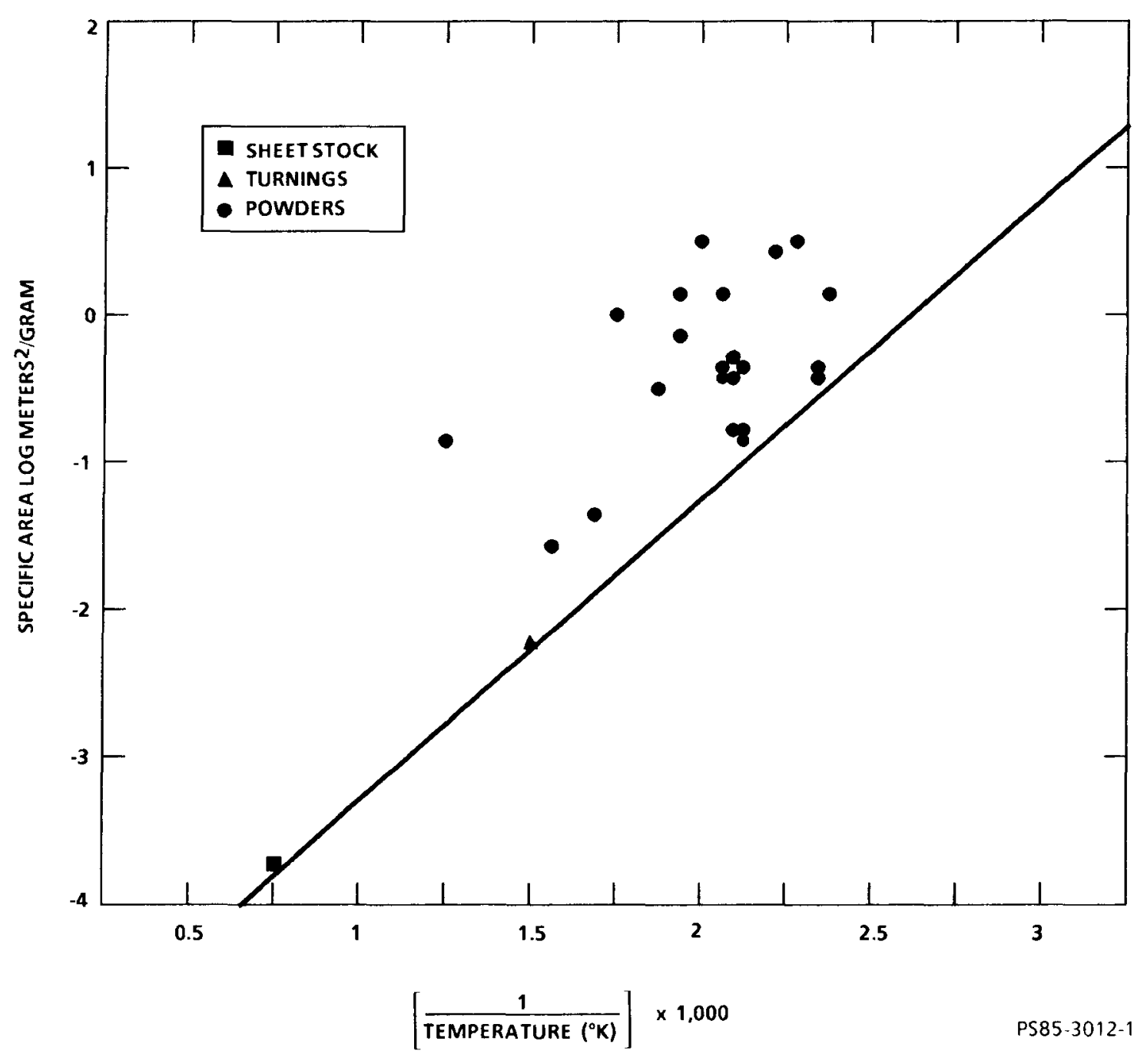

FIGURE 1. Ignition Temperature of Zirconium Metal as a Function of Surface Area Per Gram (from Reference 1). 


\section{RHO-RE-ST-31 P}

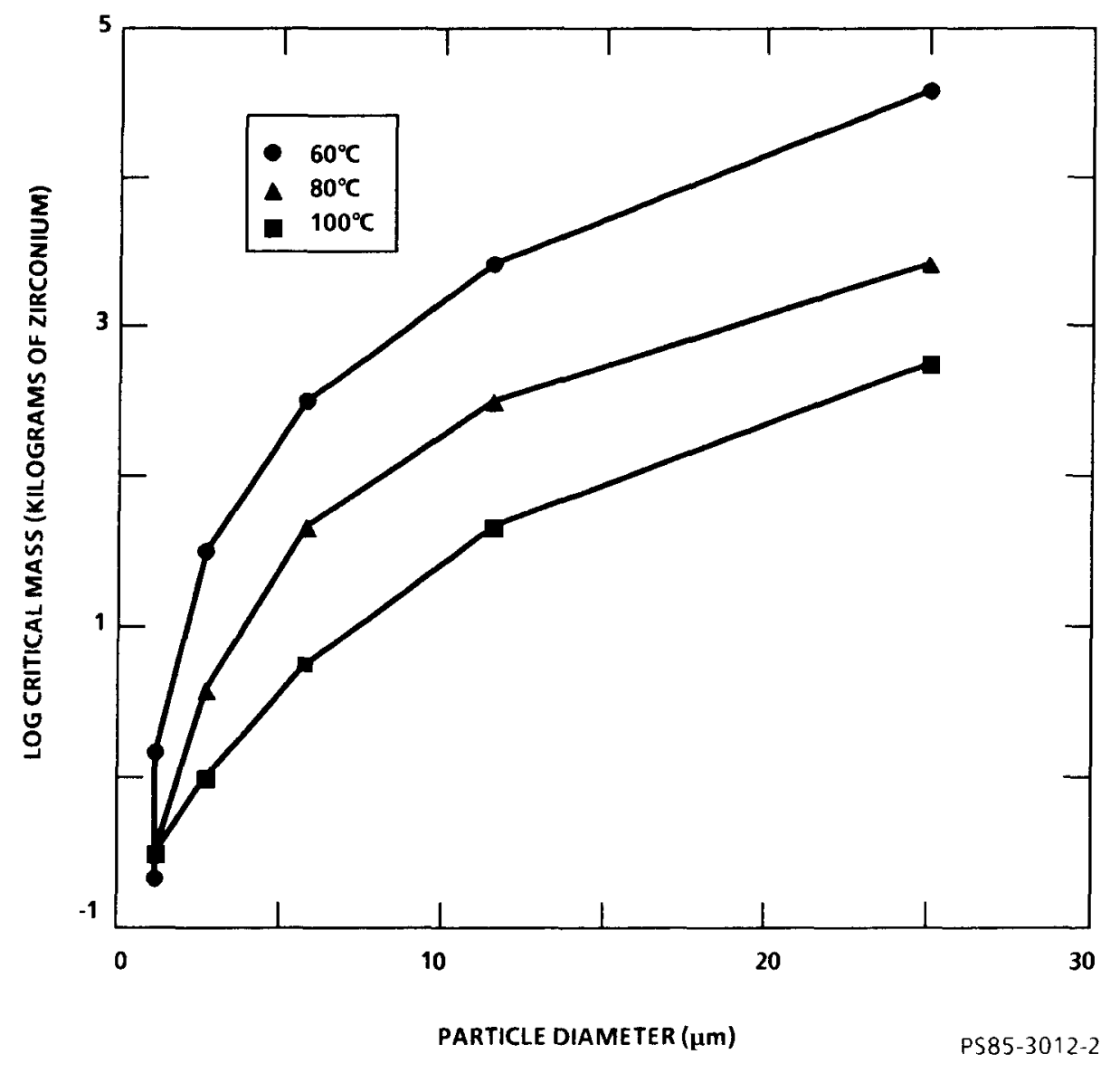

FIGURE 2a. Relationship of Critical Mass to

Particle Size for Ignition of Zirconium

(from Reference 2). 
RHO-RE-ST-31 P

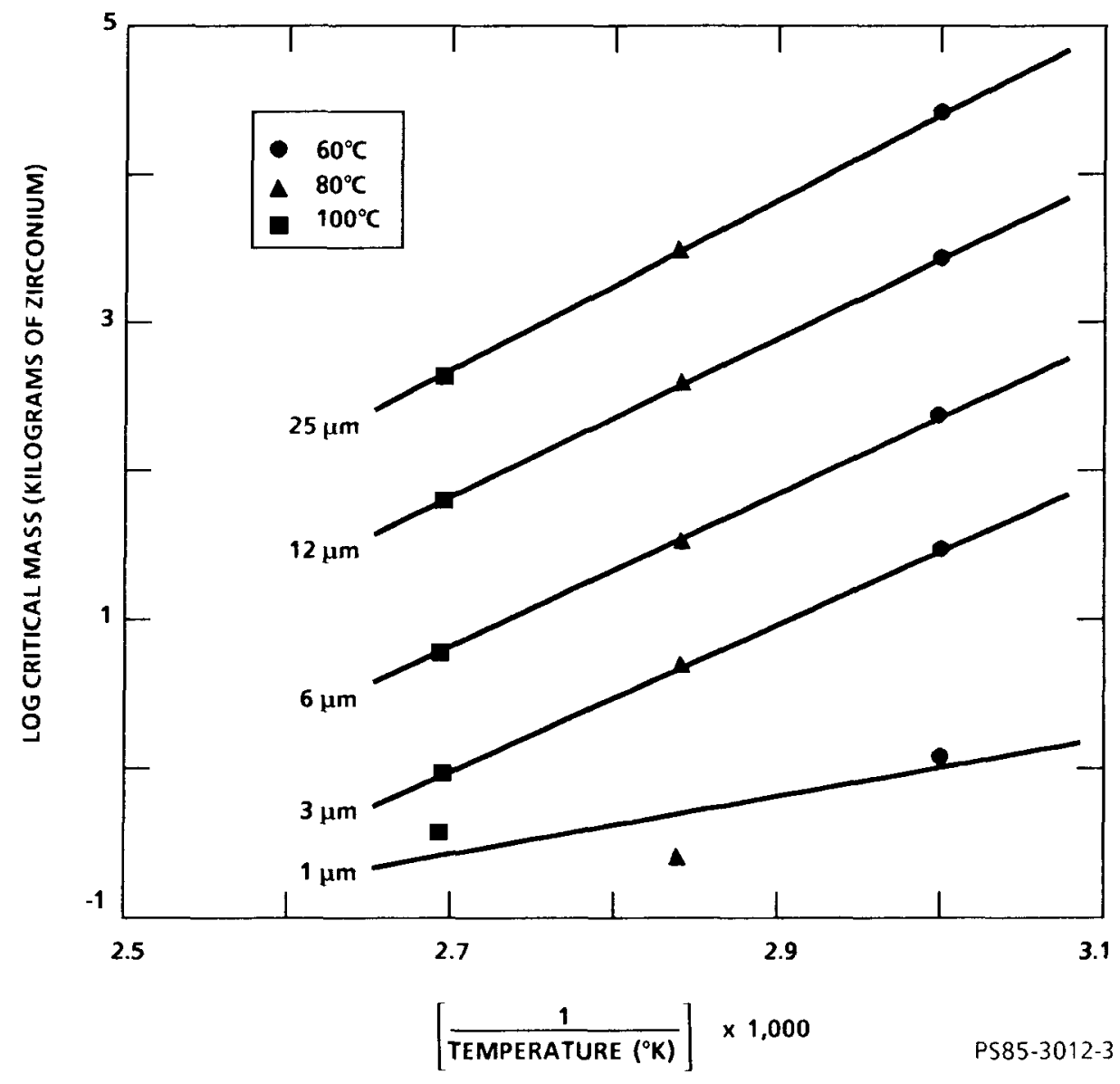

FIGURE 2b. Relationship of Critical Mass to Temperature for Various Particle Sizes of Zirconium (from Reference 2). 


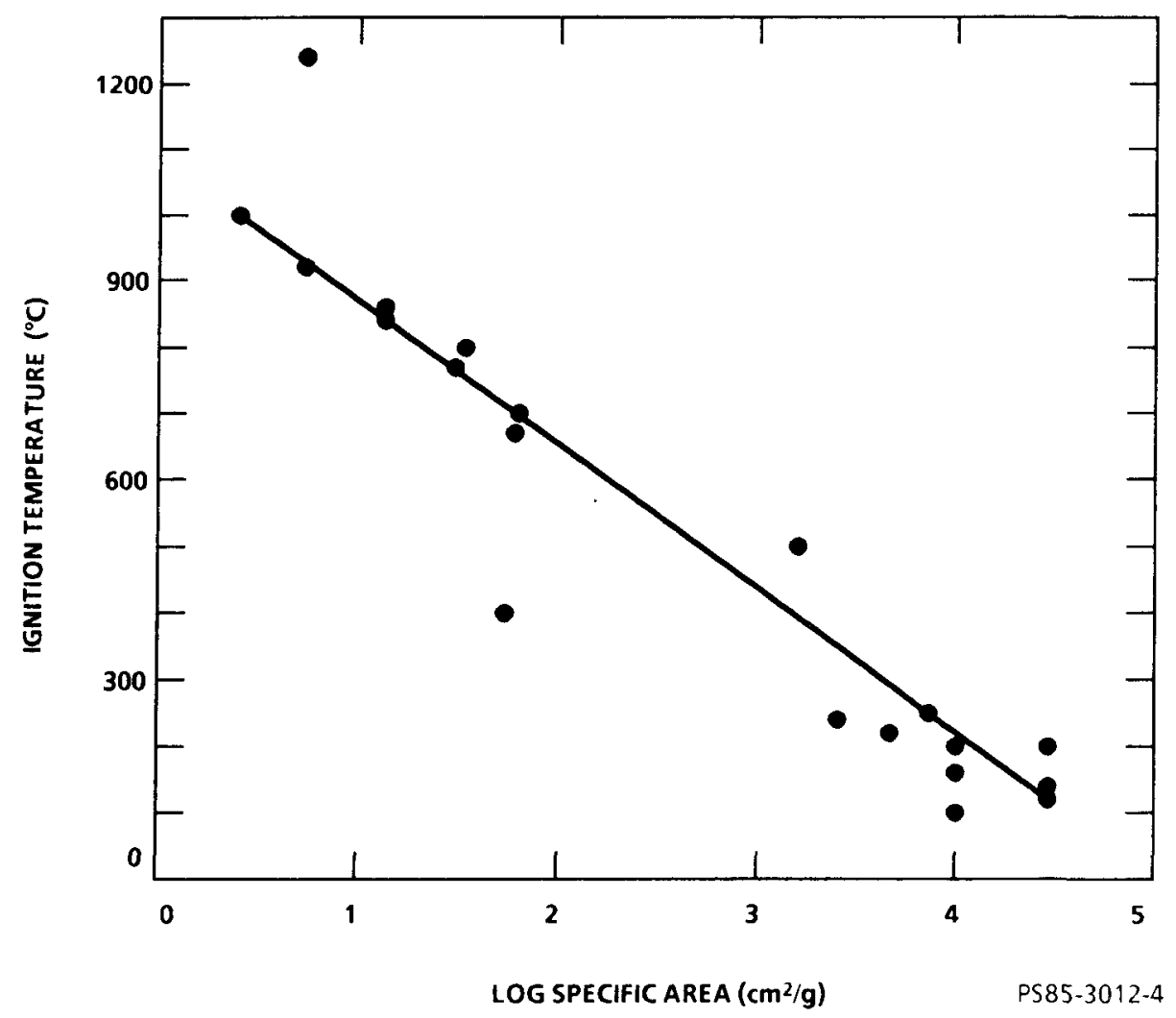

FIGURE 3. Ignition Temperature of Zirconium as a Function of Specific Area (Ignition Temperature $=1070-208 \log ($ Area $/$ Mass $)$ ) (from Reference 2). 
ignite without sparking at room temperature. Figure 4 (from Reference 3 ) is presented for titanium. It may be seen that the igniting energy drops to an approximate plateau value at $2 \mathrm{oz}$ of dust/ft $\mathrm{ft}^{3}$. The plateau is not surprising since this is a very high dust loading.

Figure 5 (from Reference 3 ) gives the limiting amount of oxygen in an inert atmosphere, below which ignition of metal dust clouds by electric sparks does not occur. For zirconium, that limit is 4 percent in argon, 3.4 percent in nitrogen, and 5 percent in helium. Carbon dioxide is not effective in limiting the ignition of zirconium dust clouds if electrically sparked.

The data presented is very consistent and points to extreme pyrophoricity of fine dry zirconium powders. A11 violent explosions of zirconium

that have resulted in fatal injuries have involved powders finer than $62 \mu \mathrm{m}$ (230 mesh).

A consensus has developed within the industry that the addition of sufficient water stabilizes zirconium powders against ignition. Powder containing up to 3 percent water by weight burns in air in the same manner as dry powder. Zirconium powder containing 3 to 15 percent water burns in air much more violently than dry powder. Above 25 percent water, most zirconium scrap is stabilized by preventing a significant temperature rise.

\subsection{ZIRCONIUM TURNINGS, SHAVINGS, AND COARSE POWDERS}

Coarse powders ( $>20$ mesh), turnings, and shavings are not pyrophoric under ambient conditions but may burn if ignited. Dry, fine zirconium scrap burns quietly with an intense white flame. Moist scrap burns violently, tossing burning scrap in the air. sizes.

Tables 4 and 5 give data relating pyrophoricity hazards to particle

The experiments reported in Reference 1 are summarized by the following.

- Fine zirconium turnings, chips, or shavings, with smallest dimensions less than 1/64 in., will always burn and continue to burn after an ignition source is removed. They are readily ignited with a safety match.

- Coarse zirconium turnings, chips, or shavings, with smallest dimensions over $1 / 16$ in., will glow, but will not burn or continue to glow after the flame of a match or the flame of a gasoline torch is removed. 
RHO-RE-ST-3I P

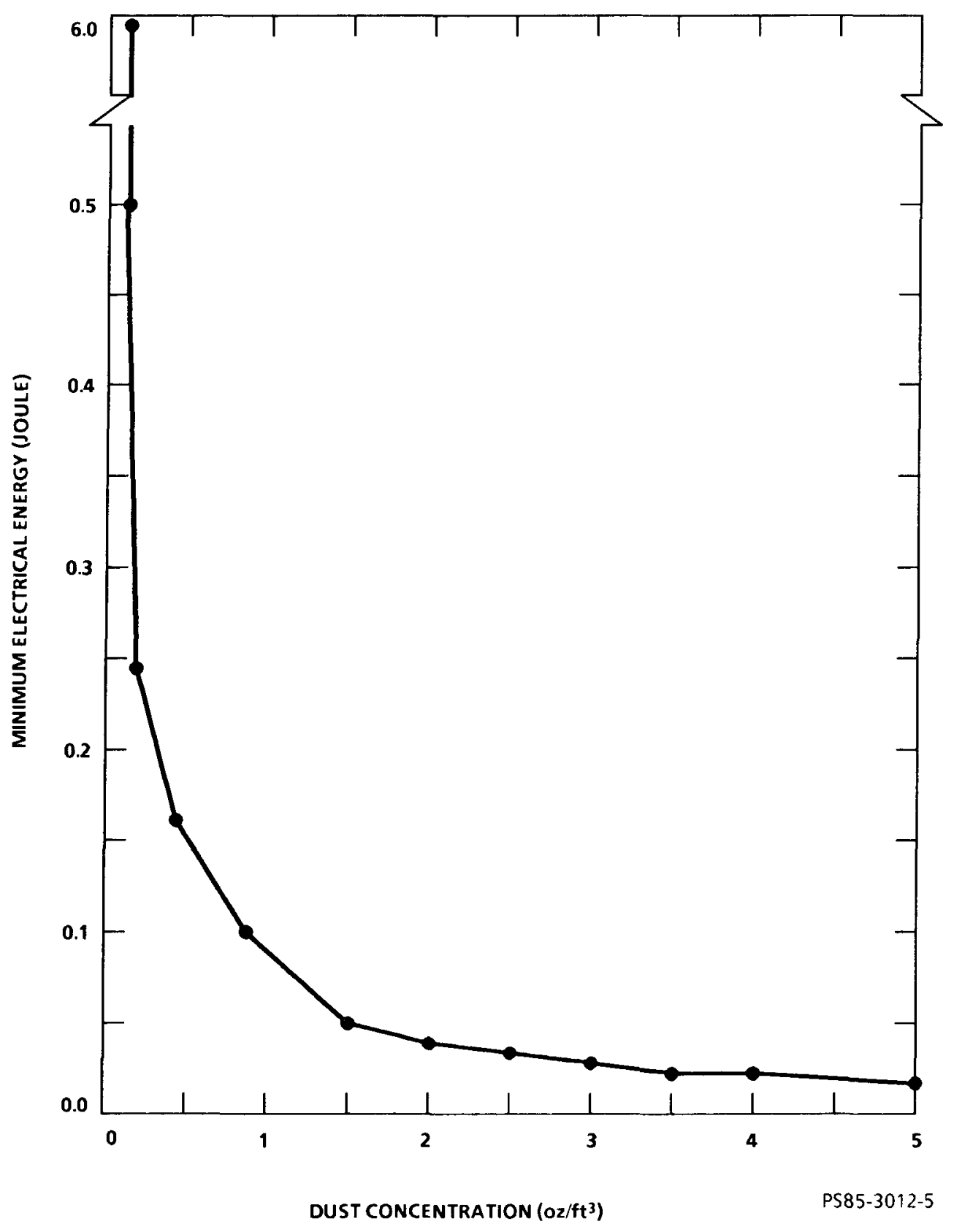

FIGURE 4. Minimum Electrical Energy to Ignite Dust Clouds of Titanium (from Reference 3 ). 


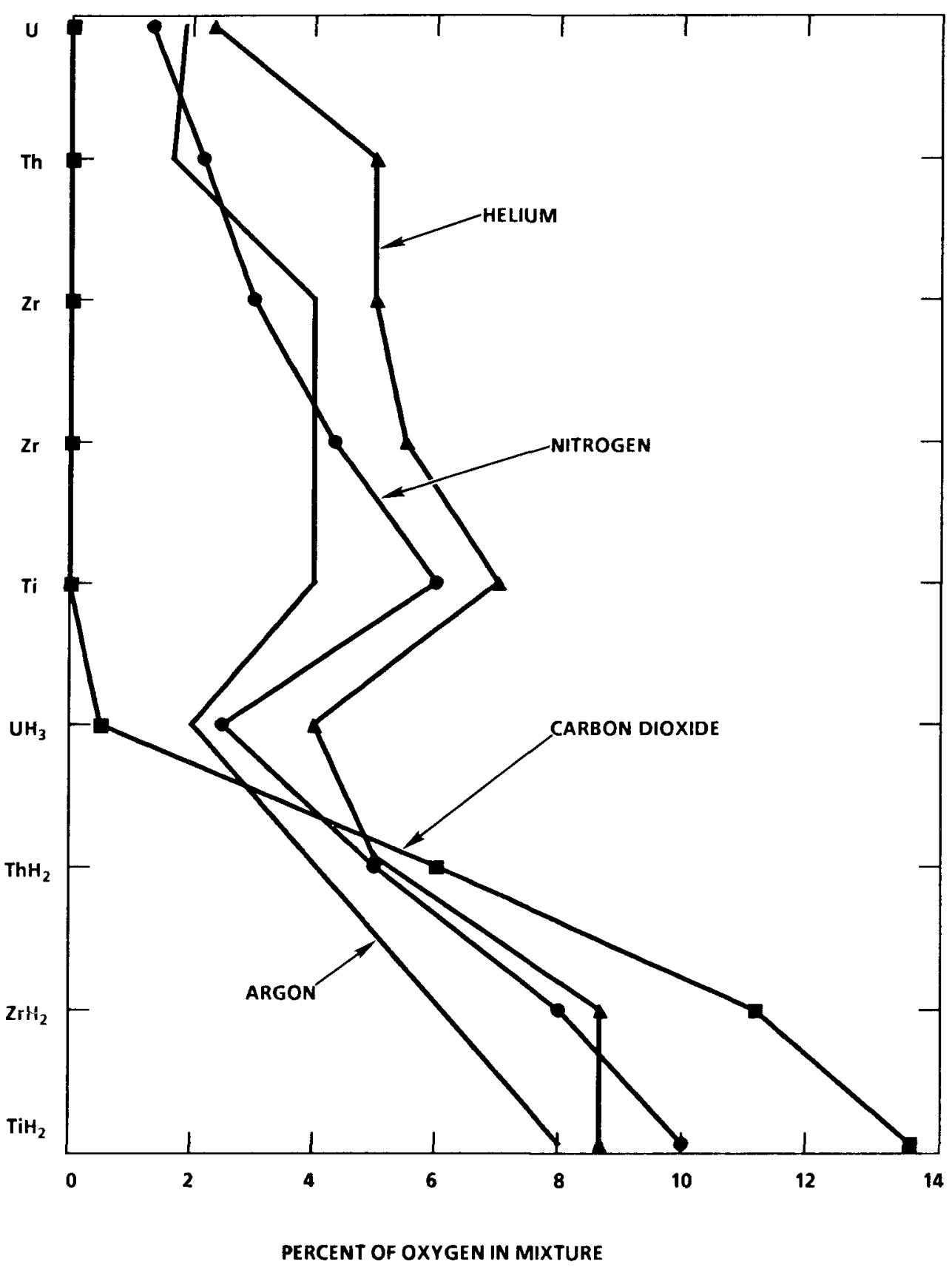

FIGURE 5. Limiting 0xygen Content in Air-Inert Gas 'Mixtures for Preventing Ignition of Dust Clouds by Electric Spark (from Reference 3). 
TABLE 4. Physical Relationships in Assessing the Safety of Zirconium Forms.

\begin{tabular}{|c|c|c|c|}
\hline \multirow{2}{*}{ Sample } & \multicolumn{2}{|c|}{ Forms } & \multirow[b]{2}{*}{ Remarks } \\
\hline & $\begin{array}{l}\text { Specific surface } \\
\text { area, } \mathrm{cm}^{2} / \mathrm{g}\end{array}$ & $\begin{array}{l}\text { Surface volume } \\
\qquad(S / V) \mathrm{cm}^{-1}\end{array}$ & \\
\hline Sphere, $1 \mu \mathrm{m}$ dia. & 9,000 & 60,000 & Pyrophoric \\
\hline Sphere, $10 \mu \mathrm{m}$ dia. & 900 & 6,000 & Pyrophoric \\
\hline Sponge & 100 & -- & Ignitable \\
\hline Sheet, $0.254 \mathrm{~mm}$ & 12.5 & 200 & $\begin{array}{l}\text { Considered the border- } \\
\text { line between safe and } \\
\text { hazardous thickness }\end{array}$ \\
\hline $\begin{array}{l}\text { Sheet, } 0.762 \mathrm{~mm} \\
(0.03 \text { in.) thick } \\
\text { (equivalent to an } \\
\text { LWR cladding hul1) }\end{array}$ & 4 & 70 & Not ignitable \\
\hline
\end{tabular}

TABLE 5. Zirconium Pyrophoricity Hazards.

\begin{tabular}{|c|c|}
\hline Metal form & Conditions enhancing pyrophoricity \\
\hline Fine powders & $\begin{array}{l}<62 \mu \mathrm{m} \text {, explosive (Reference 5) } \\
<10 \mu \mathrm{m} \text {, explosive (Reference 5) }\end{array}$ \\
\hline Coarse powders & $\begin{array}{l}<840 \mu \mathrm{m},>125 \mu \mathrm{m}, \text { flammable } \\
\text { (Reference } 5) \\
<853 \mu \mathrm{m},>10 \mu \mathrm{m}, \text { fire and } \\
\text { explosion risk (Reference 5) }\end{array}$ \\
\hline Chips, pieces & $\begin{array}{l}<0.013 \mathrm{~cm} \text { thick, <0.159 cm wide, } \\
\text { easily ignitable (Reference } 5 \text { ) } \\
<0.025 \mathrm{~cm} \text { thick, combustion self- } \\
\text { sustaining (Reference } 5 \text { ) } \\
<0.14 \mu \mathrm{m},>0.084 \mathrm{~cm} \text { thick, } \\
\text { ignitable with flame (Reference 5) }\end{array}$ \\
\hline Damp material & $\begin{array}{l}3 \text { to } 16 \text { wt\% moisture, spontaneous } \\
\text { combustion and explosion (Reference } 4 \text { ) }\end{array}$ \\
\hline
\end{tabular}

NOTE: These data relate to industrial experience involving unirradiated Zircaloys. 
- Coarse zirconium metal with ends over $1 / 8$ in. by $1 / 16$ in. will glow and melt under a $2500^{\circ} \mathrm{F}$ flame, but will not glow or burn after the flame is removed.

- Coarse zirconium machinings over $1 / 8$ in. by $1 / 16$ in. in cross section will not ignite from a match, bunsen burner, or any ordinary flames; but, any quantity over about $.115 \mathrm{~L}$, when in contact with fine white-hot burning zirconium, will ignite and sustain combustion.

- Zirconium turnings and chips present a fire hazard in quantities greater than $1 \mathrm{~L}$, and the intensity of the fire hazard becomes greater with an increase in quantity and with a decrease in the size of the end sections of the pieces.

- Zirconium cuttings and fines underwater in leak-proof containers are generalily very safe even when exposed to fire.

\subsection{MASSIVE ZIRCONIUM METAL}

Combustion experiments were performed (Reference 5) with zirconium metal chunks (approximately 2 in. long by $1 / 2$ in. dia.). It was concluded that open flames or cans of burning zirconium sponge would not ignite these chunks. A blue-black oxide scale formed upon the surface of the chunks, which prevented ignition.

Combustion tests were performed on Zircaloy tubing sections (Reference 6). 0xidation tests were performed on single sections of unirradiated Zircaloy tubing at 700,800 , and $900^{\circ} \mathrm{C}$ for one-hour periods. The average oxidation rate essentially tripled for each $100^{\circ} \mathrm{C}$ temperature rise; however, ignition did not occur.

A series of ignition tests with single 8-mm-long sections of unirradiated Zircaloy-4 tubing were made at Teledyne Wah Chang Albany Company, using zirconium igniter powders. The test data are presented in Table 6 (Reference 6 ). These test data show that tubing with a $0.8-\mathrm{mm}$ wall did not ignite even with an 8:1 weight ratio of igniter powder to tubing, although surface oxidation was evident. Temperatures of $1600^{\circ} \mathrm{C}$ were reached in some cases.

In another experiment, self-heating of Zircaloy, indicative of a sustained reaction, has been observed in tests involving the reaction of Zircaloy with steam at temperatures in the region of the melting point $\left(1850^{\circ} \mathrm{C}\right)$.

In another experiment, shock tests were performed that ignited zircaloy tubing at the melting point, but burning was not sustained and the samples self-extinguished.

These tests agree with the general conclusions drawn from the literature that massive metal pieces, including Zircaloy hul1s, do not represent a pyrophoricity or combustion hazard. 
TABLE 6. Ignition Tests Performed on Zircaloy Tubing Sections.

\begin{tabular}{|c|c|c|c|c|c|c|}
\hline $\begin{array}{c}\text { Test } \\
\text { number }\end{array}$ & $\begin{array}{r}\text { Powder } \\
\text { mass, g }\end{array}$ & $\begin{array}{l}\text { Powder } \\
\text { to tube } \\
\text { wt. ratio }\end{array}$ & $\begin{array}{l}\text { Powder } \\
\text { ignition } \\
\text { temperature } \\
\left({ }^{\circ} \mathrm{C}\right)\end{array}$ & $\begin{array}{l}\text { Burn } \\
\text { time, s }\end{array}$ & $\begin{array}{c}\text { Temperature } \\
\left({ }^{\circ} \mathrm{C}\right)\end{array}$ & Remarks \\
\hline $\begin{array}{l}1 \\
2 \\
3 \\
4 \\
5 \\
6 \\
7\end{array}$ & $\begin{array}{l}0.375 \\
1.50 \\
3.0 \\
6.0 \\
6.0 \\
6.0 \\
6.0\end{array}$ & $\begin{array}{l}0.25 \\
1 \\
2 \\
4 \\
8 \\
8 \\
4\end{array}$ & $\begin{array}{l}430 \\
430 \\
430 \\
430 \\
430 \\
400 \\
400\end{array}$ & $\begin{array}{l}30 \\
80 \\
50 \\
70 \\
25 \\
60 \\
50\end{array}$ & $\begin{array}{r}822 \\
585 \\
941 \\
894 \\
1150 \\
798 \\
1098\end{array}$ & $\begin{array}{l}\text { Tubing did not } \\
\text { ignite; all } \\
\text { tubes had an } \\
\text { oxidized sur- } \\
\text { face after the } \\
\text { test. }\end{array}$ \\
\hline $\begin{array}{l}8 \\
9\end{array}$ & $\begin{array}{l}6.0 \\
6.0\end{array}$ & $\begin{array}{l}4 \\
4\end{array}$ & $\begin{array}{l}400 \\
400\end{array}$ & $\begin{array}{l}65 \\
70\end{array}$ & $\begin{array}{l}1600 \\
1600\end{array}$ & $\begin{array}{l}\text { Burning powder } \\
\text { plus torch } \\
\text { used in } \\
\text { attempt to } \\
\text { ignite tubing. } \\
\text { Tubing glowed } \\
\text { but ceased } \\
\text { with torch } \\
\text { removal. }\end{array}$ \\
\hline
\end{tabular}

NOTES: Tubing section dimensions: $8 \mathrm{~mm}$ in length by $15 \mathrm{~mm}$ in dia. with a 0.8 -mm wall for all tests except tests 5 and 6 , which used a halfring section; corresponding weights were 15 and $0.75 \mathrm{~g}$.

Ignition powders:

Heat source:

Initial conditions:
300 mesh $(50 \mu \mathrm{m})$ Zircaloy-2 powder prepared by hydriding-dehydriding step for tests $1-5 ; 10-20 \mu \mathrm{m}$ zirconium sponge powder (leached for removal of residual $\mathrm{HgCl}_{2}$ ) for tests 6-9.

Gas torch; in addition, an oxygen torch was used in test 9.

Materials at ambient conditions on a ceramic base. 
One exception to the above conclusion is the pyrophoric behavior of acid-sensitized surfaces. After nitric acid pickling, both zirconium metal and zirconium alloys have on occasion been observed to release a brilliant white flash and a sound like a 22-caliber rifle shot (Reference 28). For zirconium-uranium alloys, this behavior is believed to be caused by the acid solution dissolving alpha-phase metal, leaving a high surface area epsilonphase that subsequently exhibits pyrophoric behavior (Reference 5). Adding hydrogen fluoride to the nitric acid desensitizes these surfaces. (References 5 and 28)

\subsection{INDUSTRIAL ZIRCONIUM INCIDENTS}

Over 30 zirconium fire or explosion incidents have been recorded in the literature; some were responsible for loss of life and limbs. A description of several of these incidents is included (Reference 4).

A number of drums containing scrap zirconium had been kept in open storage for 3 to $5 \mathrm{yr}$. Minor spontaneous fires were reported in this store from time to time. On May 14, 1956, however, one drum suddenly exploded. The right arm of an employee 20 to $40 \mathrm{ft}$ away was blown off; a second employee was seriously burnt; a third employee, who was blown a distance of $80 \mathrm{ft}$ from the drum, lost his left leg. Two employees died from the ir injuries.

A sample believed to contain zirconium, magnesium, and magnesium chloride was treated to remove the magnesium chloride by repeated leaching in changes of water. The first operations were carried out without incident, but on the last attempted operation, the sample exploded. The explosion shattered the laboratory bench on which the work was being carried out, blew out a window, and permanently disfigured the employee.

While opening 1-gal cans containing powdered zirconium (16 percent moisture wt\%), a ball of flame enveloped the area, accompanied by a definite explosion and shock wave. Two employees were killed and two were injured in this incident.

A spontaneous fire occurred in 1955, resulting in the burning of approximately 70 tons of scrap zirconium. The fire was noted initially as smoke in one of the storage bins, which almost immediately burst into flame. The fire then spread rapidly horizontally along the row of bins, and an orange flame, generating intense heat, rose to a height of $80 \mathrm{ft}$. This lasted for one minute and was followed by quiescent burning of the metal. The heat was sufficient to cause cracking of glass windows and ignition of wooden frames $100 \mathrm{ft}$ away from the fire.

Explosions have been reported by the Massachusetts Institute of Technology and the Hanford Site during the dissolution of low percentage zirconium with uranium alloys in nitric acid. It is considered that this 
is due to differing rates of solution of zirconium and uranium, whereby an extremely active form of zirconium is produced as a surface layer

(Reference 5).

These incidents are reminders that certain forms of zirconium metal must be handled, stored, and shipped under carefully controlled conditions.

The hazard of zirconium exists primarily in metal shapes of high surfaceto-mass ratio such as fine powders. Mechanically produced powder less than 270 mesh $(54 \mu \mathrm{m})$, chemically produced powder less than 20 mesh $(841 \mu \mathrm{m})$, and zirconium sheet equal to or less than $0.3 \mathrm{~mm}$ thick are considered to be flammable solids.

Throughout the literature there are many examples of spontaneous ignition of metal powder but only a few instances of the spontaneous ignition of massive metal, notably uranium and magnesium. In these latter instances, generally very heavy cutting forces were used, and ignition was brought about by a hot chip falling into a pile of finer turnings.

It is the general conclusion of this report that all zirconium sheet equal to or greater than $0.3 \mathrm{~mm}$ thick, and solid fragments whose minimum dimension exceeds $1 / 8$ in., can be considered safe from sustained combustion. Pyrophoric zirconium metal should be handled, stored, and shipped underwater or under inert gas cover to minimize the hazard of explosion or combustion. The only exception to the above guidelines is that powder less than $1 \mu \mathrm{m}$ in diameter should be immediately oxidized under controlled combustion conditions instead of being stored.

\subsection{RECOMMENDATIONS FOR HANDLING, SHIPPING, AND STORAGE}

\subsection{HANDLING}

Numerous published laboratory experiments have proven that the presence of water does not change the ignition temperature of zirconium. However, once zirconium ignites, it extracts oxygen from water, liberating hydrogen in the process. Dry zirconium burns with a quiet, white-hot flame; wet zirconium burns violently, tossing burning debris fifty feet or more into the air. A low-pressure shock wave traveling $2,000 \mathrm{ft} / \mathrm{s}$ is a distinct probability when wet zirconium ignites.

Despite the inability of water to raise the ignition temperature and despite the violence of combustion of wet zirconium, water is universally used in 25 percent (of zirconium weight) or greater amounts to stabilize powdered zirconium. This is successful, since water acts as a heat sink and typically prevents the zirconium from reaching its combustion temperature. If the water is allowed to boil away during extended heating, the zirconium will combust as described above. 
The effectiveness of water as a heat sink was dramatically illustrated by an experiment wherein pyrophoric powder (in a drum) was covered by water and the drum was placed in the center of four drums of dry powder. The dry powder was ignited and the resulting heat melted the central drum down to the water line, but did not boil away enough water to ignite the wet zirconium powder.

As a consequence of these and other experiments, the following simple handling and storage recommendations for zirconium powder have evolved:

- Eliminate other combustible materials (1imit source and spread of fire)

- Maintain moisture content below 3 percent by weight (References 4 and 6 ), or else submerge completely

- Avoid use of water or $\mathrm{CO}_{2}$ fire extinguishers in the event of a fire. It is preferable to let burning zirconium expire of its own accord. If necessary, dry, inert powders such as "Meta $1-x$ " may be used (References 4 and 29)

- Use water-soluble oils in machining

- Avoid accumulations of fine material. Dust accumulations should be less than $20 \mathrm{~g} / \mathrm{m}^{2}$

- Avoid ignition sources

- Avoid high temperatures

- Use diluent, such as sand, at least $1: 1$ by volume

- Consider use of inert gas such as argon in special situations

- Avoid mixing zirconium with other metals

- Provide venting or hydrogen recombiners for containers

- Separate zirconium work areas from adjacent activities

- Compact scrap where feasible to enhance safety

- Avoid "fuse" conditions whereby a relatively large mass of normally safe material may be ignited by a small mass of pyrophoric material

- Exercise extreme care in opening sealed drums or containers and in transferring contents

- Handle and collect all fines (less than $850 \mu \mathrm{m}$ dia.) underwater. 


\subsection{SHIPPING}

Certain forms of zirconium metal are classified as hazardous material under 49 CFR 172.101. Specific Department of Transportation (DOT) packaging specifications may be found in 49 CFR 173.214 and 173.220. These regulations require specification packaging for zirconium powder smaller than 20 mesh if chemically produced or smaller than 270 mesh if mechanically produced. A11 massive metal forms are exempt from specification packaging.

In addition to the DOT regulations, other regulations pertaining to the shipment of radioactive wastes must be considered for contaminated materials. These additional requirements must be determined independently of this report.

\subsection{STORAGE}

Large massive pieces of zirconium metal may be stored safely for long storage periods. Massive pieces may be defined as sheets $0.3 \mathrm{~mm}$ thick or thicker, and fragments or pieces whose smallest dimension is $1 / 8$ in. or larger.

For smaller particles, wet submerged storage underwater is advisable to minimize the chance of temperature rise that could reach the ignition temperature.

For mechanically produced powders less than $54 \mu \mathrm{m}$ in diameter, water or inert gas submerged storage is mandatory. Although water storage greatiy diminishes the chance of accidental fire or explosion, several dangers peculiar to water storage must be considered and prevented:

- Freezing - Aqueous solutions may expand and rupture the storage container upon freezing and thawing. Antifreeze solutions may be used to prevent this occurrence.

- Drying - If the container is overheated and/or ruptured, the liquid may drain out, leaving the contents in the 3 to 15 percent moisture range that causes the most violent fires and explosions. Furthermore, the draining liquid carries in suspension the lightest and most pyrophoric powder. Upon drying, this powder may act as a pyrophoric fuse that may in turn ignite the container contents.

In the event that damp scrap is involved in an external fire, an extremely violent explosion approaching a low order detonation with shock fronts moving at 1,000 to $2,000 \mathrm{~m} / \mathrm{s}$ is a real probability. 
- Hydrogen Accumulation - Finely divided zirconium reacts slowly with cold water, producing hydrogen that increases the risk of an explosion. The hydrogen evolution rate increases as a function of surface area and temperature. Significant hydrogen concentrations may be achieved with certain combinations of surface area, temperature, and storage time. Hydrogen, produced by zirconium in sealed containers in the presence of water, may be frictionally sparked on opening these containers. (Reference 4)

Burning of finely divided zirconium powder or scrap to produce the oxide produces the most stable waste form. Burning is typically advised if fine zirconium scrap cannot be recycled quickly. Burning is a relatively hazardous task, although it may be performed safely under rigorously controlled conditions. Typically, zirconium burning is performed in an isolated facility with stringent mass limits to control the rate of combustion. Descriptions of zirconium combustion facilities are found in References 4 and 5 .

\subsection{SUMMARY}

Massive zirconium metal scrap can be handled, shipped, and stored with no evidence of combustion or pyrophoricity hazards. Mechanically produced fine scrap such as shavings, turnings, or powders can burn but are not pyrophoric unless the particle diameter is less than $54 \mu \mathrm{m}$. Powders with particle diameters less than $54 \mathrm{\mu m}$ can be both pyrophoric and explosive. Pyrophoric powders should be collected and stored underwater or under inert gas cover to reduce the flammability hazard. Opening sealed containers of zirconium stored underwater should be attempted with caution since hydrogen may be present.

The factors that influence the ignition temperature have been explored in depth and recommendations are included for the safe handling, shipping, and storage of pyrophoric or flammable zirconium.

\subsection{REFERENCES}

1. W. R. DeHollanderer, An Evaluation of the Zirconium Hazard, HW-44989, Hanford Atomic Products Operation, Richland, Washington (August 1956).

2. N. M. Levitz, B. J. Jullen, and M. J. Steindler, Management of Waste Cladding Hul1s, Part 1-Pyrophoricity and Compaction, ANL-8139, Argonne National Laboratory, Argonne, Illinois (February 1975).

3. I. Hartmann, J. Nagy, and M. Jacobsen, Explosive Characteristics of Titanium, Zirconium, Thorium, Uranium, and Their Hydrides, R. I. 4835, U.S. Bureau of Mines, Washington, D.C. (December 1951). 
4. F. B. Holt and S. G. Wilson, A Code of Practice for the Handling of Zirconium and Its Alloys, IGR-TN-S-578, United Kingdom Atomic Energy Authority, Great Britian (July 1957).

5. W. W. Allison, Zirconium, Zircaloy, and Hafnium--Safe Practice Guide for Shipping, Storing, Handling, Processing, and Scrap Disposal, WAPD-TM-17 (Rev.), Bettis Atomic Power Laboratory, Pittsburgh, Pennsylvania (December 1960).

6. B. Kullen, N. Levitz, and M. Steindler, An Assessment of Zirconium Pyrophoricity and Recommendations for Handling Waste Hul1s, ANL-77-63, Argonne National Laboratory, Argonne, I11inois (November 1977).

7. M. Jacobsen, A. Cooper, and J. Nagy, Explosibility of Metal Powders, R.I. 6516, U.S. Bureau of Mines, Washington, D.C. (1964).

8. S. J. Coe and N. J. Sanders, The Measurement of the Ignition Temperature of Zirconium and Zircaloy Powder, AEEW-M-1841, Technology Division AEE Winfrith, Dorchester, Dorset (February 1981).

9. J. K. Dawson, V. C. Baugh, and J. F. White, "Observations on the Early Stages of Oxidation of Zirconium and Zircaloy-2," Electromechanical Technology 4(3-4):137-42 (March-April 1966).

10. E. A. Gulbransen and K. F. Andrew, "Oxidation of Zirconium and Zirconium Alloys in Water Vapor Atmospheres Containing Trace Amounts of Oxygen at $375^{\circ}$ and $575^{\circ} \mathrm{C}, "$ Electrochemical Technology 4(3-4) (MarchApril 1966).

11. W. B. Harris, Health and Safety in Powder Metal Handling, NYO-4869, U.S. Atomic Energy Commission, New York Operations (Apri1 1957).

12. E. W. Krans, "How One Company Avoids Zirconium Pyrophoricity Hazard," Nucleonics 15(8):72 (August 1957).

13. U.S. AEC, Fire and Explosion Hazards of Metallic Zirconium, GEH-23, 029, U.S. Atomic Energy Commission, Washington, D.C. (June 20, 1956).

14. Argonne, Metal Oxidation and Ignition, ANL-RCV-SL-1180, Parts I and II, Argonne National Laboratory, Argonne, Illinois (February 1957, declassified April 1957).

15. R. B. Smith, "Pyrophoricity: Technical Mystery Under Vigorous Attack," Nucleonics 14:28-33 (December 1956).

16. F. E. Littman and F. M. Church, Reactions of Titanium with Water and Aqueous Solutions, AECU-3675, U.S. Atomic Energy Commission, Menlo Park, California (March 1958).

17. E. L. Stout, Safety Considerations for Hand1ing Plutonium, Uranium, Thorium, the Alkali Metals, Zirconium, Titanium, Magnesium, and Calcium, LA-2147, Los Alamos National Laboratory, Los Alamos, New Mexico (September 4, 1951). 
18. J. A. Herickes, et a1., Zirconium Hazards Research Progress Report \#1, AECU-3642, U.S. Atomic Energy Commission, Pittsburgh, Pennsylvania (August 1957).

19. J. A. Herickes and P. A. Richardson, Zirconium Hazards Research Progress Report \#2, AECU-3682, U.S. Atomic Energy Commission, Pittsburgh, Pennsyivania (February 1958).

20. R. B. Long, Zirconium Reports Regarding Accidents, Storage, and Hand ling, GEH-23,087, Westinghouse Electric Corporation, Pittsburgh, Pennsylvania (August 1956).

21. M. L. Smith, A Survey of the Pyrophoricity Hazards of Ruptured Fuel Elements, HW-48013, Hanford Atomic Products Operation, Richland, Washington (January 28, 1957).

22. J. H. Kitte1, Spontaneous Ignition of Highly Irradiated Fuel, TID-2508 (December 1955).

23. W. C. Ruebsamen and J. B. Chrisney, Metal-Water Explosions, NAA-SR-Memo-75 (July 10, 1951, declassified June 22, 1956).

24. A. J. Bendler, Fast Transient Heating and Explosion of Metals Under Stagnant Liquids, AECU-3623, U.S. Atomic Energy Commission, Columbia University, New York (February 1958).

25. J. J. Roseman, "Hazards of Zirconium," Memo DC-59-9-223, Genera1 Electric Company, Atomic Products Division, Cincinnati, Ohio (September 28, 1959).

26. L. S. Ne1son, "Explosion of Burning Zirconium Droplets Caused by Nitrogen," Science 148:1594-5 (June 18, 1965).

27. H. Anderson and L. Belz, Factors Controlling the Combustion of Zirconium Powders, Foote Mineral Co. (April 1952).

28. National Fire Protection Association, "Zirconium," National Fire Codes $\underline{3}$ (1982).

29. I. Hartman, J. Nagy, and H. Brown, Inflammability and Explosibility of Metal Powders, R.I. 3722, U.S. Bureau of Mines, Washington, D.C. (0ctober 1943). 


\section{DISTRIBUTION}

Number of Copies

OFFSITE

20

$E G \& G$

P.0. Box 88

Middletown, PA 17057

Harold Burton

2

U.S. Department of Energy Technical Information Center P.0. Box 62

Oak Ridge, TN 37830

ONSITE

U.S. Department of Energy Richland Operations Office Richland, WA 99352

M. Dayani

Rockwe11 Hanford Operations

14

T. D. Cooper (5)

J. 0. Henrie (5)

Document Control (2)

Publications Services

Station 3 (2) 